\title{
GAMBARAN TINGKAT AKTIFITAS FISIK PADA MASYARAKAT KELURAHAN TOMANG JAKARTA BARAT
}

\author{
Susy Olivia Lontoh ${ }^{1}$, Meilani Kumala ${ }^{2}$, Novendy ${ }^{3}$ \\ ${ }^{1}$ Bagian Ilmu Fisiologi, Fakultas Kedokteran, Universitas Tarumanagara \\ Email:susyo@fk.untar.ac.id \\ ${ }^{2}$ Bagian Ilmu Gizi, Fakultas Kedokteran, Universitas Tarumanagara \\ Email:melkum58@yahoo.com \\ ${ }^{3}$ Bagian Ilmu Ilmu Kesehatan Masyarakat, Fakultas Kedokteran Universitas Tarumanagara \\ Email: novendy@fk.untar.ac.id
}

Masuk: 28-07-2020, revisi: 17-10-2020, diterima untuk diterbitkan: 27-10-2020

\begin{abstract}
ABSTRAK
Aktifitas fisik yang kurang menjadi faktor risiko untuk peningkatan kejadian penyakit jantung koroner (PJK), diabetes mellitus tipe 2 (T2DM), kanker payudara, kanker usus besar dan mengurangi harapan hidup. Tingkat aktifitas fisik yang teratur dan memadai sangat penting untuk mengurangi risiko penyakit tidak menular. Kelurahan Tomang berwilayah diperkotaan serta merupakan daerah urban dan cenderung sedentary life style. Data mengenai gambaran aktifitas fisik di lingkungan Kelurahan Tomang Jakarta Barat masih terbatas. Penelitian ini bertujuan untuk mengetahui gambaran tingkat aktifitas fisik pada masyarakat kelurahan Tomang Jakarta Barat. Penelitian yang dilakukan merupakan penelitian analitik observational dengan disain potong lintang. Penelitian dilakukan pada 181 subyek dan pengambilan subjek dilakukan secara consecutive sampling. Subjek dalam penelitian ini berusia mulai dari 20 tahun - 45 tahun dengan usia rata-rata adalah $35.1 \pm 6,79$ tahun, mayoritas adalah perempuan sebanyak 55,8 \% dan 78,5\% subjek menikah. Dilihat dari jenjang pendidikan, didominasi dengan pendidikan SMA/sederajat, rata-rata penghasilan perbulan 42,9 \% subjek berpenghasilan Rp.3.000.001,-Rp.4.000.000,- dan sebagian besar subjek bekerja sebagai ibu rumah tangga serta $43,1 \%$ subjek yang tidak melakukan olahraga. Hasil pengukuran tingkat aktifitas fisik subjek terlihat bahwa 59,7\% subjek yang memiliki aktifitas ringan dan jenis kelamin dan jenis pekerjaan berpengaruh terhadap kurangnya aktifitas fisik.
\end{abstract}

Kata Kunci: aktifitas fisik, sedentary life style

\begin{abstract}
Lack of physical activity is a risk factor for increased incidence of coronary heart disease (CHD), type 2 diabetes mellitus (T2DM), breast cancer, colon cancer and reduced life expectancy. Regular and adequate levels of physical activity are essential to reduce the risk of non-communicable diseases. Kelurahan Tomang has an urban area and is an urban area and tends to be a sedentary life style. Data regarding the description of physical activity in the Tomang Village, West Jakarta is still limited. This study aims to determine the level of physical activity in the community of Tomang Village, West Jakarta. This research is an observational analytic study with a cross-sectional design. The study was conducted on 181 subjects and subject taking was done by consecutive sampling. Subjects in this study were aged from 20 years - 45 years with an average age of $35.1 \pm 6.79$ years, the majority were women as much as $55.8 \%$ and $78.5 \%$ of the subjects were married. Judging from the level of education, dominated by high school education / equivalent, the average monthly income of 42.9\% of the subjects earned Rp. 3,000,001,-Rp. 4,000,000, - and most of the subjects worked as housewives and $43.1 \%$ of subjects who did not exercise. The results of the measurement of the subject's physical activity level showed that $59.7 \%$ of subjects who had light activity and sex and type of work had an effect on the lack of physical activity.
\end{abstract}

Keywords: physical activity, sedentary life style 


\section{PENDAHULUAN}

Gaya hidup atau lifestyle yang kurang baik menjadi perhatian secara global dan merupakan beban bagi kesehatan masyarakat. Aktifitas fisik yang kurang merupakan contoh gaya hidup yang kurang baik. Ketidakaktifan fisik menjadi faktor risiko untuk peningkatan kejadian penyakit jantung koroner (PJK), diabetes mellitus tipe 2 (T2DM), kanker payudara, kanker usus besar dan mengurangi harapan hidup (Kyu, H. H. et al., 2013). Ketidakaktifan fisik diidentifikasi sebagai faktor risiko utama keempat untuk kematian global dan merupakan penyebab utama sekitar 21-25\% kanker payudara dan usus besar, 27\% diabetes dan $30 \%$ beban penyakit jantung iskemik. Tingkat aktifitas fisik yang teratur dan memadai sangat penting untuk mengurangi risiko penyakit tidak menular (WHO, 2017).

Berdasarkan data penelitian masyarakat yang tidak aktif dibandingkan dengan masyarakat yang kurang aktif (setara dengan 600-3999 MET-menit) memiliki 14\% pengurangan resiko T2DM, 16\% pengurangan risiko PJK dan 3\% pengurangan risiko kanker payudara. Risiko dari semua penyakit ini semakin menurun dengan dilakukan peningkatan aktifitas fisik yang lebih tinggi (Kyu, H. H. et al., 2013). Secara keseluruhan, penurunan 10\% tingkat populasi tidak aktif diharapkan terjadi penurunan angka kematian setengah juta kematian global setiap tahunnya.

Peningkatan aktifitas fisik menjadi strategi sederhana dan murah untuk mengatasi peningkatan angka obesitas dan penyakit kronis secara global (Love, R. et al., 2018). Non communicable diseases (NCD) menjadi tantangan kesehatan masyarakat di dunia. Peningkatan skala epidemi NCD khususnya di Asia Tenggara, seperti di Indonesia menjadi beban kesehatan yang sangat besar dan menimbulkan permasalahan perekonomian khususnya bagi masyarakat di kalangan berpenghasilan rendah dan menengah (WHO, 2014). Predisposisi genetik, urbanisasi, layanan kesehatan yang tidak memadai, pola hidup sedentari serta perubahan pola makan berkontribusi terhadap peningkatan penyakit tidak menular di Indonesia (Schröder, et al., 2017).

Dewasa ini, sebagian masyarakat Indonesia cenderung mempunyai aktifitas fisik rendah yang disebabkan perubahan pola kerja, aktifitas sehari-hari, kemajuan teknologi khususnya bidang elektronik dan transportasi, dan gaya hidup yang bermalas-malasan. Rendahnya kebugaran fisik disebabkan oleh rendah kualitas kesehatan dan gaya hidup yang kurang bergerak menyebabkan produktifitas kerja yang rendah. Produktifitas kerja yang rendah yang menghasilkan Indeks Pembangunan Manusia yang rendah (HDI). Berdasarkan laporan UNDP (United Program Pembangunan Bangsa) 2014, Indonesia berada di peringkat 119 dari 125 negara. (Prabowo, A.,et al., 2020).

Jakarta merupakan daerah urban dengan gaya hidup yang santai, kondisi ini juga berlaku pada Kelurahan Tomang berwilayah diperkotaan serta merupakan daerah urban. Sebagian besar masyarakat kelurahan Tomang menghabiskan waktu lebih dari 8 jam untuk bekerja atau aktifitas dalam rumah tangga dan 2 hingga 4 jam di perjalanan, baik menuju kantor ataupun pulang ke rumah, yang membuat tidak adanya waktu untuk bergerak aktif sehingga cenderung menyebabkan ketidakaktifan fisik. Pandemik Covid-19 terjadi pembatasan skala besar, 
cenderung aktifitas masyarakat Indonesia banyak dilakukan dirumah, kegiatan yang banyak dilakukan duduk serta nonton TV. Data mengenai gambaran aktifitas fisik di lingkungan Kelurahan Tomang Jakarta Barat masih terbatas. Penelitian ini bertujuan untuk mengetahui gambaran tingkat aktifitas fisik pada masyarakat kelurahan Tomang Jakarta Barat.

\section{METODE PENELITIAN}

Penelitian yang dilakukan merupakan penelitian analitik observational dengan disain potong lintang. Subjek penelitian adalah populasi yang memenuhi kriteria inklusi meliputi laki laki dan perempuan berumur 20-45 tahun dan bersedia menandatangani informed consent. Penelitian dilakukan pada 181 subyek dan pengambilan subjek dilakukan secara consecutive sampling. Subjek penelitian diberi penjelasan mengenai penelitian yang akan dilakukan dan diminta untuk menandatangani informed consent jika bersedia mengikuti penelitian. Pengambilan data menggunakan kuisioner yang terdiri dari kuisioner dengan karakteristik subjek yaitu usia, jenis kelamin, status pernikahan, tingkat pendidikan, olahraga, penghasilan dan jenis pekerjaan. Kuesioner untuk mengukur tingkat aktifitas fisik yang digunakan adalah physical activity level (PAL). Teknik analisis data yang digunakan yaitu teknik analisis deskriptif yang bertujuan untuk mengetahui gambaran responden dan aktifitas fisik. Pada kuisioner aktifitas fisik subjek diminta untuk menuliskan aktifitas selama 3 hari mengenai apa saja yang dilakukan selama sehari dalam kurun waktu 24 jam dalam lembar recall aktifitas. Menurut FAO/WHO/UNU (2001), besarnya aktifitas fisik yang dilakukan seseorang dalam 24 jam dinyatakan dalam physical activity level (PAL) atau tingkat aktifitas fisik. PAL dapat ditentukan dengan rumus sebagai berikut:

$\mathrm{PAL}=\sum(\mathrm{PARxW}) / 24$

Keterangan : PAL : Physical Activity Level, PAR : Physical Activity Ratio, W : Alokasi waktu dalam 24 jam . Kategori tingkat aktifitasfisik berdasarkan nilai PAL (FAO/WHO/UNU, 2001) :

a) Ringan (sedentary lifestyle) $=1,40-1,69$

b) Sedang (active or moderately active lifestyle) $=1,70-1,99$

c) Berat (vigorous or vigorously active lifestyle) $=2,00-2,40$

\section{HASIL DAN PEMBAHASAN}

\section{Karakteristik Subjek}

Distribusi karakteristik subjek menurut usia, jenis kelamin, status pernikahan, tingkat pendidikan, olahraga, penghasilan dan jenis pekerjaan dapat dilihat pada tabel 1. Subjek yang mengikuti penelitian ini terdiri dari 181 orang. Subjek dalam penelitian ini berusia mulai dari 20 tahun sampai 45 tahun dengan usia rata-rata adalah $35.1 \pm 6,79$ tahun. Mayoritas subjek adalah perempuan sebanyak 55,8\% dan 78,5\% subjek menikah. Dilihat dari jenjang pendidikan, didominasi dengan pendidikan SMA/sederajat kemudian diikuti dengan jenjang SMP, SD, S1, Diploma dan tidak sekolah . Pada keadaan ini dapat dilihat bahwa tingkat pendidikan di wilayah Tomang masih kurang baik karena berdasarkan data yang didapat ada 
masyarakat Tomang yang tidak bersekolah. Rata-rata penghasilan perbulan 42,9 \% subjek berpenghasilan Rp.3.000.001,-Rp.4.000.000,- dan sebagian besar subjek bekerja sebagai ibu rumah tangga. Berdasarkan frekuensi berolahraga didapatkan hasil subjek yang tidak melakukan olahraga sebanyak 43,1\%. Berdasarkan data sebaran dari hasil penelitian didapatkan bahwa subjek bekerja sebagai ibu rumah tangga dan karyawan. Subjek yang sebagian besar ibu rumah tangga ini melakukan aktifitas rutin sebagai ibu rumah tangga, seperti memasak, mencuci piring, menyetrika, mengepel lantai, merawat anak dan sama sekali tidak ada subjek yang melakukan kegiatan aktifitas berat seperti olahraga akan tetapi rata-rata subjek lebih banyak melakukan aktifitas diluar rumah dengan berjalan kaki dari pada menggunakan alat transportasi seperti sepeda, motor maupun mobil. Hasil penelitian ini sesuai dengan penelitian yang dilakukan oleh Novitasary, dkk yang melaporkan bahwa subjek pada penelitian ini berjumlah 77 orang bekerja sebagai ibu rumah tangga dan memiliki aktifitas ringan (Novitasary,dkk 2013).

Berdasarkan sebaran data karakteristik subjek maka subjek pada usia produktif, serta sebagian besar berpenghasilan dibawah UMR. Subjek yang sebagian besar karyawan, ojek online, wirausaha lebih cenderung melakukan kegiatan pekerjaan untuk memenuhi kebutuhan seharihari. Durasi kerja yang dilakukan panjang serta mereka jarang melakukan kegiatan olahraga. Hal ini dapat dilihat berdasarkan data sebaran dari kegiatan olah raga bahwa sebagian besar subjek berolahraga kurang dari 3 kali/perminggu. Menurut anjuran WHO olahraga sebaiknya dilakukan rutin seminggu 3 kali selama 30 menit. Karyawan terutama pekerja kantoran memiliki kecenderungan untuk kurang aktif fisik. Sebagian besar waktu dihabiskan di kantor (kurang lebih 8 jam per hari) dan aktifitas yang cenderung sedentari diduga menjadi penyebab kurang aktifnya para karyawan. Dapat dikatakan terdapat hubungan terbalik panjangnya durasi waktu kerja melakukan aktifitas fisik pada karyawan. Pekerjaan yang dilakukan karyawan cenderung tidak banyak memerlukan kegiatan aktifitas fisik. Selain itu dengan pemanfaatan teknologi membuat karyawan menjadi malas untuk bergerak aktif (Kirk, et al., 2013).

Kurang berolahraga membuat aktifitas fisik menjadi kurang dan hal ini membuat orang memiliki pola hidup sedentari. WHO menganjurkan melakukan setidaknya 150 menit aktifitas fisik intensitas sedang sepanjang minggu, atau melakukan setidaknya 75 menit aktifitas fisik intensitas kuat sepanjang minggu, atau kombinasi yang setara dari aktifitas intensitas sedang dan kuat (WHO, 2010). Aktifitas fisik adalah gerakan tubuh yang dilakukan otot-otot rangka dan mengeluarkan sejumlah energi untuk melakukan berbagai kegiatan. Berdasarkan penelitian didapatkan bahwa rendahnya aktifitas fisik merupakan faktor risiko untuk terjadinya penyakit tidak menular. Besarnya aktifitas fisik yang dilakukan seseorang selama 24 jam dinyatakan dalam physical activity level atau tingkat aktifitas fisik yang diklasifikasi ringan, sedang dan berat (Plowman, S., et al., 2014).

Aktifitas fisik berkaitan dengan kebugaran jasmani yaitu kesanggupan dan kemampuan tubuh melakukan penyesuaian terhadap beban fisik yang diberikan tanpa menimbulkan kelelahan 
yang berlebihan. Kebugaran Jasmani berhubungan dengan kebugaran kardiovaskuler, kekuatan otot, keseimbangan tubuh dan kelenturan. Perkembangan teknologi menjadi salah satu penyebab beralihnya aktifitas dinamis menjadi statis yang menyebabkan menurunnya tingkat kebugaran jasmani dan menurunnya daya tahan kardiovaskuler. (Plowman, S., et al., 2014).

Tabel 1. Distribusi karakteristik subjek menurut usia, jenis kelamin, status pernikahan, tingkat pendidikan, olahraga, pendapatan dan jenis pekerjaan

\begin{tabular}{|c|c|c|}
\hline Variabel & $\mathbf{N}(\%)$ & Nilai \\
\hline Usia (tahun) & & 35,$1 ; 06,79(20 ; 45)$ \\
\hline $20-29$ & $35(19,3)$ & \\
\hline $30-45$ & $146(80,7)$ & \\
\hline \multicolumn{3}{|l|}{ Jenis kelamin } \\
\hline Laki-Laki & $80(44,2)$ & \\
\hline Wanita & $101(55,8)$ & \\
\hline \multicolumn{3}{|l|}{ Status Nikah } \\
\hline Tidak Menikah & $39(21,5)$ & \\
\hline Menikah & $142(78,5)$ & \\
\hline \multicolumn{3}{|l|}{ Pendidikan Terakhir } \\
\hline Tidak Sekolah & $1(0,6)$ & \\
\hline $\mathrm{SD}$ & $14(7,7)$ & \\
\hline SMP & $43(23,8)$ & \\
\hline SMA/Sederajat & $111(61,2)$ & \\
\hline Diploma & $5(2,8)$ & \\
\hline Sarjana (S1) & $7 \quad(3,9)$ & \\
\hline \multicolumn{3}{|l|}{ Olahraga } \\
\hline Tidak Olahraga & $78(43,1)$ & \\
\hline \multicolumn{3}{|l|}{ Berolahraga } \\
\hline$\leq 3 \mathrm{kali} / \mathrm{minggu}$ & $89(49,2)$ & \\
\hline$\geq 4 \mathrm{kali} / \mathrm{minggu}$ & $14(7,7)$ & \\
\hline \multicolumn{3}{|l|}{ Pendapatan (perbulan) } \\
\hline$<$ Rp.1.000.000,- & $17(10)$ & \\
\hline Rp.1.000.001 - Rp 2.000.000,- & $28(16,5)$ & \\
\hline Rp.2.000.001 - Rp.3.000.000,- & $39(22,9)$ & \\
\hline Rp.3.000.001 - Rp. 4.000.000,- & $73(42,9)$ & \\
\hline Rp 4.000.001 - Rp. 5.000.000,- & $12(7,1)$ & \\
\hline$>$ Rp.5.000.000,- & $1(0,6)$ & \\
\hline \multicolumn{3}{|l|}{ Jenis Pekerjaan } \\
\hline Tidak Bekerja & $5(2,8)$ & \\
\hline Ojek Online & $11(6,1)$ & \\
\hline Ibu Rumah Tangga & $81(44,8)$ & \\
\hline Karyawan & $75(41,4)$ & \\
\hline Wirausaha & $9(5)$ & \\
\hline
\end{tabular}


Hasil pengukuran tingkat aktifitas fisik subjek digambarkan pada tabel 2 dan hasil yang terlihat bahwa 59,7\% subjek yang memiliki aktifitas ringan. Berdasarkan data tersebut dapat dilihat sebagian besar masyarakat Tomang memiliki gaya hidup sedentary life style. Hasil penelitian tingkat aktifitas fisik subjek di Tomang lebih tinggi dibandingkan penelitian Abadini dkk (2019) yang dilakukan pada pekerja kantoran di Jakarta didapatkan prevalensi aktifitas fisik yang kurang sebesar 59\%. Hasil penelitian ini didukung dengan data sebaran karakteristik subjek yaitu sebagian besar subjek merupakan karyawan dan ibu rumah tangga. Karyawan memiliki kecenderungan untuk kurang aktif fisik, sebagian besar waktunya dihabiskan dikantor dan hal ini yang menyebabkan aktifitasnya bersifat sedentari. Sedentari pada pekerja dapat disebabkan oleh beberapa hal, diantaranya adalah jenis pekerjaan, hobi atau kesenangan, fasilitas yang mendukung perilaku sedenteri serta kurang berolahraga (Fadila, 2016). Aktifitas fisik yang dilakukan oleh ibu rumah tangga dikategorikan ringan, karena sehari-harinya aktifitas fisik yang dilakukan adalah memasak, membersihkan rumah dan mencuci pakaian (Novitasary, et al., 2013). Berdasarkan data Riskesdas (2018) proporsi penduduk Indonesia yang melakukan aktifitas fisik adalah $33,3 \%$. Sementara proporsi penduduk Indonesia yang berperilaku santai yaitu $\geq 6$ jam perhari sebesar 24,1\%. Dengan demikian aktifitas fisik penduduk Indonesia masih rendah. Pada Riset Kesehatan Dasar tahun 2013 (Kementerian Kesehatan RI, 2013), Berdasarkan Riskesdas 2013 kriteria aktifitas fisik aktif adalah individu yang melakukan aktifitas fisik berat atau sedang sedangkan kurang aktif adalah individu yang tidak melakukan aktifitas fisik sedang atau berat.

Tabel 2. Sebaran Tingkat Aktifitas Fisik berdasarkan PAL

\begin{tabular}{lr}
\hline Variabel & $\mathbf{N}(\%)$ \\
\hline Aktifitas Fisik & \\
Ringan $(1,40-1,69)$ & $108(59,7)$ \\
Sedang $(1,70-1,99)$ & $46(25,4)$ \\
Berat $(2,00-2,40)$ & $27(14,9)$ \\
& \\
\hline
\end{tabular}

Pada sebaran data tabel 3 ditemukan jenis kelamin dan jenis pekerjaan berpengaruh terhadap kurangnya aktifitas fisik. Berdasarkan data di atas dapat dilihat sebagian besar masyarakat Tomang memiliki kebiasaan aktifitas fisik yang kurang aktif terutama wanita, hampir sebagian besar berprofesi ibu rumah tangga dan $100 \%$ subjek yang tidak bekerja memiliki aktifitas kurang aktif. Subjek yang tidak bekerja memiliki kebiasaan menonton tv, main game yang membuat orang betah untuk duduk berjam-jam. Aktifitas fisik sedentari sering dilakukan dalam kehidupan sehari-hari dan pola aktifitas fisik di negara berkembang dan transisi cenderung memberikan kontribusi lebih kecil terhadap total pengeluaran energi. Aktifitas dirumah lebih bersifat aktifitas fisik rekreasi daripada aktifitas terkait pekerjaan atau transportasi. (Milton, K., et al., 2014). Gaya hidup sedentari tanpa disadari dilakukan oleh hampir seluruh ibu rumah tangga di Indonesia. Pola aktifitas ibu rumah tangga setelah melakukan pekerjaan rumah tangga, lebih sering duduk maupun berbaring. Hasil ini sesuai dengan penelitian yang dilakukan Nur Asih (2017) tentang aktifitas fisik ibu rumah tangga 
yang dihubungkan dengan kegemukan dan obesitas didapatkan sebagian besar subjek termasuk dalam kategori aktifitas fisik ringan seperti lebih sering melakukan aktifitas dengan bantuan alat teknologi seperti transportasi, dan alat-alat elektronik yang membantu meringankan pekerjaan rumah tangga. Ketika menonton televisi, mendengarkan radio, berbincang-bincang bersamaan dengan makan atau mengkonsumsi makanan ringan. Sebagian orang gaya hidup sedentari merupakan seseorang kurang melakukan gerak atau pun kurang melakukan aktifitas fisik, gaya hidup yang santai sebagian waktunya waktu yang dihabiskan untuk duduk maupun berbaring kecuali waktu tidur (Australian Goverment Department of Health, 2014).

Tabel 3. Distribusi subjek berdasarkan karakteristik individu dan aktifitas fisik

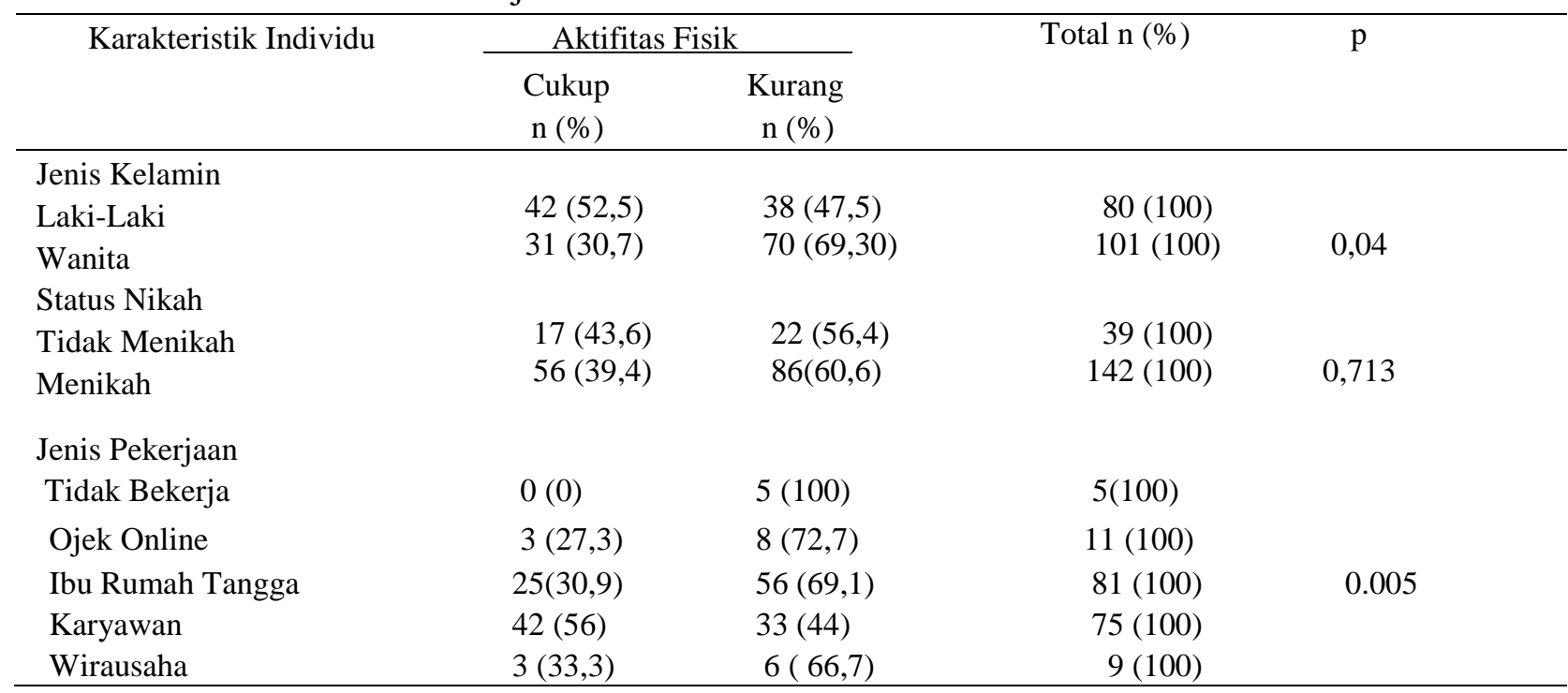

\section{KESIMPULAN DAN SARAN}

\section{Kesimpulan}

Berdasarkan hasil pengukuran tingkat aktifitas fisik ditemukan 59,7 \% subjek memiliki aktifitas ringan dan jenis kelamin dan jenis pekerjaan berpengaruh terhadap kurangnya aktifitas fisik.

\section{Saran}

Penelitian selanjutnya dilakukan dengan mengukur IMT, asupan gizi pada masyarakat Tomang serta mengukur tekanan darah, kadar gula darah untuk mengetahui gambaran PTM di kelurahan Tomang dan dilakukan edukasi terkait aktifitas fisik. 


\section{REFERENSI}

Abadini, D., \& Wuryaningsih, C. (2019). Determinan aktifitas fisik orang dewasa pekerja kantoran di Jakarta tahun 2018. Jurnal Promosi Kesehatan Indonesia, 14(1 ): 15-28.

Australian Goverment Department of Health. (2014). Australia's physical activity and sedentary behaviour guidlines. Dikutip 22 Juli 2019. Website: https://www.physiopedia.com/Australia\%27s_Physical_Activity_and_Sedentary_Behaviour_Guidelines

Fadila, I. ( 2016). Relasi perilaku sedentari, gizi lebih, dan produktivitas kerja masyarakat perkotaan. Dikutip 22 Juli $2019 . \quad$ Website: http://repository.ut.ac.id/7087/1/UTFMIPA2016-03-ila.pdf

FAO/WHO/UNU. (2001). Human energy requirements. WHO Technical Report Series No. 724. Geneva: World Health Organization. Dikutip 22 Juli 2019. Website: https://www.who.int/nutrition/publications/nutrientrequirements/9251052123/en/

Kementerian Kesehatan RI. (2013). Laporan Hasil Riset Kesehatan Dasar 2013. Jakarta: Departemen Kesehatan RI.

Kirk, M.A., \& Rhodes, R.E. (2011). Occupation correlates of adults' participation in leisure-time physical activity: A systematic review. Am J Prev Med, 40(4):476-485.

Kyu, H. H., et al. (2013). Physical activity and risk of breast cancer, colon cancer, diabetes, ischemic heart disease, and ischemic stroke events: systematic review and dose-response meta-analysis for the Global Burden of Disease Study. BMJ 354, i3857. Dikutip 22 Juni 2020. Website: https://doi.org/10.1136/bmj.i3857

Love, R., Adams, J., Van, E., Foster, C., \& Humphreys, D. (2018). A cumulative meta-analysis of the efects of individual physical activity interventions targeting healthy adults. Obesity Reviews, 19(8): 1164-1172 Dikutip 22 Juli 2020 Website DOI: 10.1111/obr.12690

Milton, K., Macniven, R., \& Bauman, A. (2014). Review of the epidemiological evidence for physical activity and health from low-and middle-income countries. Global public health, 9 (4),369-338.

Novitasary, M., Maluyu, N., \& Kawengian S. (2013). Hubungan antara aktifitas fisik dengan obesitas pada wanita usia subur peserta jamkesmas di puskesmas Wawonasa Kecamatan Singkil Manado. Jurnal Fakultas Kedokteran Universitas Sam Ratulangi, e-Biomedik, 1(2):1040-1046. Dikutip 22 Juli $2020 . \quad$ Website: https://ejournal.unsrat.ac.id/index.php/ebiomedik/article/view/3255/2799

Nur, R. (2017). Perilaku makan dan aktifitas fisik ibu rumah tangga yang kegemukan dan obesitas di Kelurahan Bunga Tanjung Kecamatan Datuk Bandar Timur Kota Tanjungbala. Dikutip 22 Juli 2020. Website: http://repositori.usu.ac.id/handle/123456789/1754

Schröders, J., Wall, S., Hakimi, M., Dewi, F.S.T., Weinehall, L. \& Nichter, M., et al. (2017). How is Indonesia coping with its epidemic of chronic noncommunicable diseases? A systematic review with meta-analysis. PLoS ONE, 12(6): e0179186. Dikutip 22 Juni 2020 Website: https://doi.org/10.1371/journal.pone.0179186

Plowman, S., \& Smith, D. (2014). Exercise physiology for health, fitness and performance. Philadelphia: Lippincott Williams \& Wilkins.

Prabowo, A., Sulaiman, \& Soenyoto, T. (2020). The effect of exercises and gender on cardiorespiratory endurance in the elderly. Journal of Physical Education and Sports, 9(2), $105-111$.

RI, Badan Penelitian dan Pengembangan Kesehatan Kementerian Kesehatan. (2018). Riset kesehatan dasar (Riskesdas) 2018.

WHO. (2010). Global recommendation on physical activity for health. Dikutip 22 Juni 2020. Website: https://apps.who.int/iris/bitstream/handle/10665/44399/9789241599979_eng.pdf?sequence $=1$ 
WHO. (2014). Global status report on noncommunicable diseases. Dikutip 22 Juni 2020 dari World Health Organization. Website: https://www.who.int/nmh/publications/ncd-statusreport-2014/en/

WHO. (2017). Global strategy on diet, physical activity and health. Dikutip 12 Juni 2020 dari World Health Organization . Website: http://www.who.int/ dietphysicalactivity/pa/en/. 
